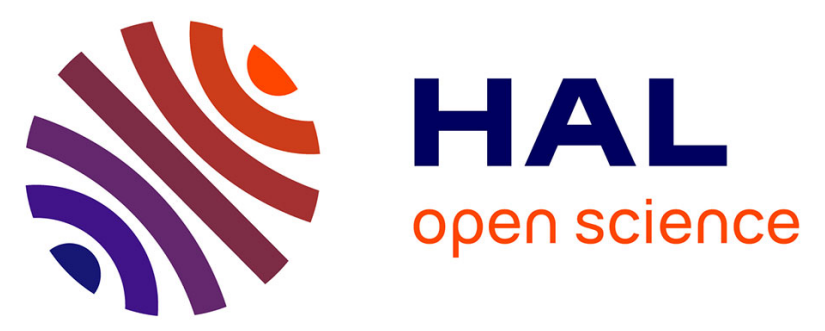

\title{
Monoterpene and sesquiterpene emissions of three Mediterranean species through calcareous and siliceous soils in natural conditions
}

Elena Ormeno, Catherine Fernandez, Anne Bousquet-Mélou, Stephane Greff, Erwan Morin, C. Robles, B. Vila, G. Bonin

\section{To cite this version:}

Elena Ormeno, Catherine Fernandez, Anne Bousquet-Mélou, Stephane Greff, Erwan Morin, et al.. Monoterpene and sesquiterpene emissions of three Mediterranean species through calcareous and siliceous soils in natural conditions. Atmospheric Environment, inPress, 41 (3), pp.629-639. 10.1016/j.atmosenv.2006.08.027 . hal-01764592

\section{HAL Id: hal-01764592 \\ https://hal-amu.archives-ouvertes.fr/hal-01764592}

Submitted on 12 Apr 2018

HAL is a multi-disciplinary open access archive for the deposit and dissemination of scientific research documents, whether they are published or not. The documents may come from teaching and research institutions in France or abroad, or from public or private research centers.
L'archive ouverte pluridisciplinaire HAL, est destinée au dépôt et à la diffusion de documents scientifiques de niveau recherche, publiés ou non, émanant des établissements d'enseignement et de recherche français ou étrangers, des laboratoires publics ou privés. 


\title{
Monoterpene and sesquiterpene emissions of three Mediterranean species through calcareous and siliceous soils in natural conditions
}

\author{
E. Ormeño*, C. Fernandez, A. Bousquet-Mélou, S. Greff, E. Morin, C. Robles, \\ B. Vila, G. Bonin
}

Equipe Ecologie Fonctionnelle, Institut Me'diterranéen d'Ecologie et Paléoécologie (IMEP), UMR, CNRS, 6116, Université de

Provence, Centre de St Jérôme, Case 421, Av. Escadrille Normandie Niemen, 13397 Marseille, France

\begin{abstract}
Little is known about terpene emissions released by plants in response to abiotic factors, except for climate-related factors. Standard emissions $\left(E_{\mathrm{S}}\right)$ of monoterpenes $\left(E_{\mathrm{SM}}\right)$ and sesquiterpenes $\left(E_{\mathrm{SS}}\right)$ o $\mathrm{f}$ Rosmarinus officinalis, Pinus halepensis and Cistus albidus in siliceous and calcareous sites were examined. Their dependency on some nutrients in these soils was also analyzed. The study was carried out in the south of France at the end of March, when C. albidus exhibited a leaf growth state, while the other two species exhibited a pre-budbreak state. The results revealed that $E_{\mathrm{S}}$ of all major monoterpenes released by $R$. officinalis and $E_{\mathrm{S}}$ of $\alpha$-pinene and $\alpha$-humulene of $P$. halepensis were higher in plants growing in calcareous soils. In contrast, for $C$. albidus, $E_{\mathrm{SM}}$ and $E_{\mathrm{S}}$ of $\beta$-bourbonene and $\alpha$-humulene were higher in siliceous soils. $E_{\mathrm{SM}}$ of all species was mainly correlated with nitrogen $(N)$ and available phosphorous $\left(\mathrm{P}_{\mathrm{A}}\right)$, while dependency on $\mathrm{Ca}^{2+}$ or $\mathrm{K}^{+}$was variable. None of these nutrients was significantly correlated with $E_{\mathrm{SS}}$, suggesting that sesquiterpene synthesis pathway requires different nutrient supplies. While higher soil nutrient content stimulated $E_{\mathrm{SM}}$ of $R$. officinalis and $P$. halepensis, it had a negative effect on $E_{\mathrm{SM}}$ of $C$. albidus, probably because $C$. albidus exhibited a different phenological state. Considering the soil nature, and particularly $\mathrm{N}$ and $\mathrm{P}_{\mathrm{A}}$ as inputs in plant terpene inventories could hence contribute to obtain more accurate terpene estimates.
\end{abstract}

Keywords: Nitrogen; Phosphorous; Terpenes; Phenological state; Soil nature

\section{Introduction}

Terpenes are one of the largest and most varied groups of plant chemicals. Their emission from

\footnotetext{
*Corresponding author. Tel.: + 33491288506; fax: +33491288707 .

E-mail address: elena.ormeno@univ-cezanne.fr (E. Ormeño).
}

plants represents one of the main sources of photochemically reactive hydrocarbons in the troposphere, since they contribute to the production of different secondary pollutants such as secondary organic aerosols (SOAs) and tropospheric ozone $\left(\mathrm{O}_{3}\right)$ (Tsigaridis and Kanakidou, 2002). Terpenes have thus been demonstrated to be important inputs into photochemical models currently used 
to simulate air quality. Different terpene types have been reported to contribute in different ways to the tropospheric photochemical imbalance. Whereas sesquiterpenes are rather implicated in aerosol formation, monoterpenes play a more important role in $\mathrm{O}_{3}$ formation (Guenther, 2002). However, while considerable effort has been devoted to the design of models capable of predicting monoterpene emissions, sesquiterpene emissions are not integrated in such models.

This effort has been particularly important in the Mediterranean area, since climatic conditions favour biogenic volatile organic compound (BVOC) emissions and especially those of terpenes (Bertin et al., 1997). These conditions include a marked seasonality, with a long summer, where the lowest precipitation rate and the highest annual irradiance coincide. This is also a highly populated area, leading to increases in anthropogenic pollutants, such as $\mathrm{NO}_{x}$, necessary for tropospheric $\mathrm{O}_{3}$ formation in the presence of BVOC and light. All these interacting phenomena are thereby responsible of the high tropospheric secondary pollution in the Mediterranean area. Because emissions of numerous Mediterranean species are dominated by monoterpenes (Owen et al., 2001), many studies have focused on monoterpene emission variation according to climate-related factors. Thus, light, temperature (Staudt and Bertin, 1998), drought (Hansen and Seufert, 1999) and the phenological state according to the season (Sabillon and Cremades, 2001) have been reported to be linked to monoterpene emissions. While sesquiterpenes may also characterize emissions of some Mediterranean species (e.g. Cistus albidus, Llusià and Peñuelas, 1998) the effect of environmental factors on these emissions is not so well documented. Considering the effect of these factors on monoterpene and sesquiterpene emissions separately could be important, not only because they do not play the same role in the troposphere, but also because they are synthesized in different cell compartments through independent synthesis pathways. Monoterpenes are synthesized through the plastidic non-mevalonate, methylerythritol-phosphate (MEP) pathway, while sesquiterpenes are mainly synthesized through the cytosolic mevalonate (MVA) pathway (Hampel et al., 2005). Moreover, after being synthesized, some species posses specialized structures (e.g. glands, resin ducts), where terpenes are accumulated prior to be released. In most cases, both monoterpenes and sesquiter- penes are accumulated (Pinus halepensis, Llusià and Peñuelas, 2000; Rosmarinus officinalis, Moretti et al., 1998), but it is possible that only sesquiterpenes are stored, even if monoterpenes contribute to emissions (C. albidus, Llusià and Peñuelas, 2000). Because emissions may depend on stored concentrations (Lerdau et al., 1995), factors modifying these structures could also modify terpene emissions potentially.

Apart from the climate, the Mediterranean region also largely features calcareous and siliceous soils (also commonly named alkaline and acid soils, respectively). These soils differ in their $\mathrm{pH}$, permeability and nutrient status (e.g. nitrogen). While some studies have shown that terpene content in the essential oil from Mediterranean species such as C. monspelliensis L., (Robles and Garzino, 2000), C. albidus (Robles and Garzino, 1998), Myrtus communis L. (Flamini et al., 2004) and $R$. officinalis (Moretti et al., 1998) vary according to these soils, no information is available on terpene emission dependency on calcareous and siliceous soils. The significant role of soil nutrient availability, particularly, soil nitrogen, on terpene emissions, has been supported by the fact that monoterpene and sesquiterpene emissions have been found to be positively correlated to nitrogen supply (Gouinguene and Turlings, 2002). Examining terpene emission dependency on soils, which differ naturally in their nutrient status, could thereby provide a basis for assessing the importance of considering these soils as an input in terpene emission inventories and models. Whereas only Gouinguene and Turlings, (2002) have dealt with terpene emission variability according to nitrogen supply in soil no attention has been paid to the effect of other soil nutrients, such as phosphorous, potassium or calcium. Some lines of evidence indicate nevertheless that these nutrients could interfere in terpene emissions. These nutrients are currently linked to plant growth and carbon assimilation (Lambers et al., 1998). Moreover, under low contents of both, nitrogen and phosphorous in natural soils, Barnola and Cedeño, (2000) showed an increase in leaf terpene content.

Here we examined in situ whether monoterpene and sesquiterpene emissions of three typical Mediterranean species (i) varied between plants growing in calcareous and siliceous soils (ii) were related to nitrogen $(\mathrm{N})$, available phosphorous $\left(\mathrm{P}_{\mathrm{A}}\right)$, calcium $\left(\mathrm{Ca}^{2+}\right)$ and potassium $\left(\mathrm{K}^{+}\right)$in soil. 


\section{Material and methods}

\subsection{Species, sites and sampling description}

Three Mediterranean storing species were chosen: Pinus halepensis Mill., Cistus albidus L., and Rosmarinus officinalis L. All grew both in calcareous and siliceous soils, but were mainly widespread on calcareous soils. The study was carried out throughout the calcareous and siliceous ranges of Provence (in the PACA Region: Provence-Alpes-Côte d'Azur), in southern France, where these two soil types are geographically well separated. Sampling took place from 19 to 24 March 2004 and between 11:00 and 15:30 h (solar time). Terpene emissions of each species were analyzed at three calcareous sites (C1, C2, C3) $\left(43^{\circ} 28^{\prime} \mathrm{N}-5^{\circ} 26^{\prime} \mathrm{E} ; 4^{\circ} 29^{\prime} \mathrm{N}-5^{\circ} 18^{\prime} \mathrm{E}\right.$; $43^{\circ} 15^{\prime} \mathrm{N}-5^{\circ} 37^{\prime} \mathrm{E}$, respectively) and three other siliceous sites (S1, S2, S3) $\left(43^{\circ} 13^{\prime} \mathrm{N}-6^{\circ} 10^{\prime} \mathrm{E}\right.$; $43^{\circ} 12^{\prime} \mathrm{N}-6^{\circ} 9^{\prime} \mathrm{E} ; 43^{\circ} 30^{\prime} \mathrm{N}-6^{\circ} 39^{\prime} \mathrm{E}$ ) (approximate distance between both types of soil: $150-200 \mathrm{~km})$. A supplementary siliceous site (S4) $\left(43^{\circ} 20^{\prime} \mathrm{N}-6^{\circ} 30^{\prime} \mathrm{E}\right)$ was chosen for $R$. officinalis alone, since this species was absent from one siliceous site (S3). Four individuals per site were studied, making a total of 12 plants per species and per soil. Mean precipitation pattern of the last 5 years in March was similar at both types of sites: 30 and $37 \mathrm{~mm}$ in calcareous and siliceous sites, respectively (Meteo France ${ }^{\mathbb{R}}$ ). Air temperature and Photosynthetically Active Radiation (PAR) during sampling were also similar for both types of soils. They ranged from 22 to $25^{\circ} \mathrm{C}$ and from 750 to $960 \mu \mathrm{mols} \mathrm{s}^{-1} \mathrm{~m}^{-2}$ throughout the sampling campaign.

\subsection{Bag enclosure system description}

For each plant, emissions from a single branch with sun and shade exposed leaves (between 3 and $7 \mathrm{~g}$ of leaf dried weight) were sampled. Health of leaves was visually checked. A semi-dynamic bag system was used to enclose a branch and trap terpene emissions from its leaves. Internal bag temperature, PAR (Portable photo system, plant and canopy transmission meter, Surechem ${ }^{\circledR}$, EMS7 Model), relative humidity (psychrometer, Jules Richard) and horizontal wind speed (Wind Speed Meter, WSC, $888 \mathrm{H}$, Huger ${ }^{\circledR}$ ) were measured with a time resolution of $2 \mathrm{~min}$, while emission sampling took place. The bag enclosure system used in this study consisted of a teflon bag (0.51). The enclosure process was done in such a way to cause little movement of leaves. After enclosing each branch within the bag system, non-polluted air was pumped into the bag. Pumping took place from the air stream inlet to the air stream outlet for $10 \mathrm{~min}$ at a mean flow of $120 \pm 30 \mathrm{ml} \mathrm{min}^{-1}$. Then, gas samples were collected at a rate of $80 \pm 30 \mathrm{ml} \mathrm{min}^{-1}$ for $12 \mathrm{~min}$. A glass tube containing solid adsorbents (Tenax TA) was placed at the air stream outlet of each bag in order to trap volatile organic compounds. The flow through each glass tube was measured with a bubble flowmeter $\left(0-280 \mathrm{ml} \mathrm{min}^{-1}\right.$, GPE Meterate 314-140/084), placed immediately after each Tenax TA. The system was designed to allow 14 measurements simultaneously. A blank with no branch in the gas exchange system was sampled at each measure.

After emission measurements, each branch sampled was cut off and stored in a portable refrigerator at $+4{ }^{\circ} \mathrm{C}$ until being stored at $-20{ }^{\circ} \mathrm{C}$ in the laboratory. Leaves from each branch were separated and lyophilized in order to measure their dry weight (DW).

The repeatability of the method was tested for each species before the experiment took place, by placing simultaneously four Tenax TA at the air stream outlet of a single teflon bag system. No differences appeared between terpene emissions trapped in the different Tenax TA for any species.

\subsection{Terpene emission analyses and standard emission $\left(E_{s}\right)$ calculation}

Tenax TA with adsorbed terpenes were analyzed through thermal desorption by gas chromatography (GC) fitted with a Flame ionization detector (FID) $\left(\mathrm{HP}^{\mathbb{R}} 5890\right.$ series II). Previous to thermal desorption, a preflush phase was run $\left(3 \mathrm{~min}, 10 \mathrm{ml} \mathrm{min}^{-1} 60^{\circ} \mathrm{C}\right)$ to allow humidity in Tenax to be evacuated. Thermal desorption (Thermal Desorption Cold Trap injector, Varian ${ }^{\circledR}$, CP4020-TCT model) was carried out through nitrogen carrier gas $(10 \mathrm{~min}$, $50 \mathrm{ml} \mathrm{min}{ }^{-1} 250{ }^{\circ} \mathrm{C}$ ) and cryogenic concentration in a silica capillary trap, cooled with liquid nitrogen at $-100^{\circ} \mathrm{C}$. Then, compounds were separated in the non-polar chromatographic column (Ultra 2, 1: $50 \mathrm{~m} \times$ i.d.: $0.2 \mathrm{~mm} \times$ f.t.: $0.25 \mu \mathrm{m})$.

The identity of most terpenes was confirmed by comparison with standards of high purity (AldrichFirminich). Calibration of monoterpene and sesquiterpene factor response, used for calculating their concentrations, was performed periodically throughout the sampling period. Calibration curves 
were always highly significant $\left(r^{2}>0.98\right)$. In few cases, when standards were not available, peak identification was achieved by injection of previously extracted terpenes from each species, in Tenax TA. The identity of these compounds was determined through a GC $\left(\mathrm{HP}^{\mathbb{R}}{ }^{6890}\right)$ coupled with a mass spectrometer (MS) (HP ${ }^{\circledR} 5973$ Network Mass Selective Detector). Their quantitative analysis was achieved by considering the average of individual response factors of compounds whose standards were available.

Standard emissions $\left(E_{\mathrm{S}}\right)$ of monoterpenes and sesquiterpenes ( $E_{\mathrm{SM}}$ and $E_{\mathrm{SS}}$, respectively) were mainly calculated following the Tingey et al. (1980) algorithm (standardisation at $30^{\circ} \mathrm{C}$ ), since temperature is considered to be the main parameter controlling emissions from terpene storing species. For $P$. halepensis, only emissions of linalool and myrcene were standardized following Guenther et al. (1995), (standardisation at $30{ }^{\circ} \mathrm{C}$ and $1000 \mu \mathrm{mol} \mathrm{m}^{-2} \mathrm{~s}^{-1}$ ) since Simon et al. (2005) reported that these compounds were both light and temperature dependent (and not only temperature dependent).

\subsection{Tree age measurement}

Since age of plants may modify their emission rates (Street et al., 1997), age of each sampled plant was also assessed. The main branch of each shrub was cut off in order to collect cross sections. Meticulous sanding of cross sections was necessary in order to evidence ring limits, since ring boundaries were difficult to detect. For each cross section, rings were counted along two radii, giving an estimation of the age of each plant. For $P$. halepensis, age was calculated following classical Methods of Dendrochronology (Schweingruber, 1988). Sampling of this species involved collecting cores as low as possible. Age was determined by counting rings of cores with pith after interdatation.

\subsection{Soil analyses}

For each experimental site, four $200 \mathrm{~g}$-soil samples from the Al horizon were collected. The main physical and chemical properties were measured (Table 1). Some of these properties were measured in the laboratory: texture, $\mathrm{pH}$, total organic carbon (TOC), total $\mathrm{N}(\mathrm{N})$ and $\mathrm{C} / \mathrm{N}$ ratio. Other properties were analyzed in other laboratories: $\mathrm{Ca}^{2+}, \mathrm{Mg}^{2+}$, and $\mathrm{K}^{+}$(Environmental and Chemical Laboratory, University of Provence, FRE 2704), available $\mathrm{P}\left(\mathrm{P}_{\mathrm{A}}\right)$ and total P (P) (Agriculture and Chemical Laboratory, Montpellier, France).

\subsection{Statistical analyses}

Results are presented in mean $\pm \mathrm{SE}$ throughout the paper. Statistical analyses of variance (ANOVA), with site as independent factor, and post hoc Tukey tests were used to analyse intra-calcareous and intra-siliceous differences with regard to (i) physical and chemical soil properties and (ii) $E_{\mathrm{S}}$ of each species. Student test was applied to test statistical calcareous and siliceous differences regarding (i) their physical and chemical properties and (ii) $E_{\mathrm{S}}$ of each species. Heterogeneity and

Table 1

Mean \pm SE (in brackets) of the physical and chemical properties of collective calcareous and siliceous sites

\begin{tabular}{llll}
\hline Soil properties & $t$ & Calcareous soils & Siliceous soils \\
\hline $\mathrm{pH}\left(\mathrm{H}_{2} \mathrm{O}\right)$ & $6.75^{* * *}$ & $7.26(0.09)$ & $5.92(0.15)$ \\
Sand $\%$ (Aubert) & $4.99^{* * *}$ & $28.06(3.61)$ & $57.95(4.41)$ \\
$\mathrm{Silt}(\%)$ (Aubert) & $3.78^{* * *}$ & $54.30(4.32)$ & $30.56(4.30)$ \\
Clay (\%) (Aubert) & $2.79^{* *}$ & $17.63(2.09)$ & $11.49(1.39)$ \\
Total organic carbon (TOC) (\%) (Anne) & $3.76^{* * *}$ & $5.05(0.50)$ & $3.04(0.27)$ \\
$\mathrm{N}(\%)(\mathrm{Kjeldhal})$ & $4.07 * * *$ & $0.74(0.13)$ & $0.21(0.02)$ \\
$\mathrm{C} / \mathrm{N}$ & $4.04^{* * *}$ & $7.68(1.51)$ & $15.63(1.11)$ \\
Total P $(\mathrm{P})\left(\mathrm{mg} \mathrm{kg}^{-1}\right)$ & $2.46^{*}$ & $1129.13(44.67)$ & $783.78(102.22)$ \\
Available P $\left(\mathrm{P}_{\mathrm{A}}\right)\left(\mathrm{mg} \mathrm{kg}^{-1}\right)(\mathrm{Olsen})$ & $2.69^{*}$ & $44.67(4.34)$ & $32.87(2.58)$ \\
$\mathrm{Ca}{ }^{2+}\left(\mathrm{mg} \mathrm{kg}^{-1}\right)$ & $23.23 * * *$ & $9332.03(456.80)$ & $1442.84(86.70)$ \\
$\mathrm{Mg}^{2+}\left(\mathrm{mg} \mathrm{kg}^{-1}\right)$ & $0.45 \mathrm{~ns}$ & $106.04(21.30)$ & $100.99(13.74)$ \\
$\mathrm{K}^{+}\left(\mathrm{mg} \mathrm{kg}^{-1}\right)$ & $5.73^{* * *}$ & $590.20(39.80)$ & $309.70(31.20)$ \\
\hline
\end{tabular}

Results of statistical differences between both soils are also shown through Student test $(t) p$ : test significance. *0.01<p<0.05, $* * 0.01<p<0.001, * * * p<0.001$. ns: not significant $(p>0.05)$. 
homogeneity among soils of the same nature and the dichotomy between calcareous and siliceous soils were represented through a Principal components analysis (PCA). For ANOVA and Student test, data were log transformed when necessary to achieve normal distribution requirements. Relationships between $E_{\mathrm{SM}}$ or $E_{\mathrm{SS}}$ and $\mathrm{N}, \mathrm{P}_{\mathrm{A}}, \mathrm{K}^{+}$and $\mathrm{Ca}^{2+}$ of soils were tested by linear and non-linear regression analyses. Statistical analyses were conducted using Statgraphics ${ }^{\circledR} 4.1$ and $\mathrm{R}^{\circledR} \quad$ 2.3.0 programs.

\section{Results}

\subsection{Physical and chemical soil differences}

Differences between calcareous and siliceous soils are mainly due to their different nutrient availability (Table 1), which explains $49 \%$ of their dichotomy (Fig. 1). In a small extent, differences are also due to their texture properties (Fig. 1B). Thus, moderately alkaline calcareous sites have a lesser permeability than acid siliceous soils and a higher nutrient availability, except for $\mathrm{Mg}^{2+}$ (Fig. 1B, Table 1). Moreover, even if soils of the same nature are quite homogeneous (Fig. 1) some significant differences are observed (ANOVA, $p<0.05$, Tukey test). For instance, S3 and S4 have the highest sand content (Fig. 1B).

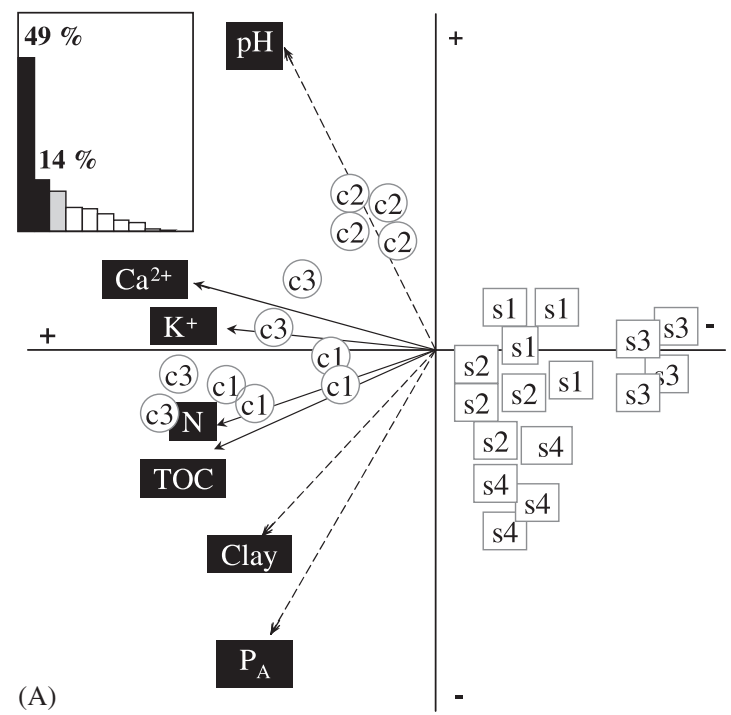

\section{2. $E_{S}$ changes on calcareous and siliceous soils}

Plants growing in sites with the same soil show similar $E_{\mathrm{SS}}$ and $E_{\mathrm{SM}}$ (ANOVA, $p>0.05$ ), except for $C$. albidus, whose $E_{\mathrm{SM}}$ is significantly higher in $\mathrm{S} 3$, than in S1 and S2 (ANOVA, $p<0.05$, Tukey test). Therefore, soil effect on terpene emissions has been tested by grouping results of sites with the same soil. Only for C. albidus, tests have been performed with and without S3. Moreover, for all species, the age of plants located in calcareous and siliceous soils was similar (Student test, $p>0.05$ ).

$R$. officinalis mostly releases monoterpenes (Fig. 2), which represent $85 \%$ of total emissions on average. Major released compounds are $\alpha$-pinene and $\beta$-pinene (Fig. 3, Table 3). $E_{\mathrm{SM}}$ of this species is significantly higher when plants grow in calcareous sites $\left(p<0.05\right.$; Fig. 2), where $E_{\mathrm{SM}}$ is 3 -fold higher than $E_{\mathrm{SM}}$ in siliceous sites. Furthermore, $E_{\mathrm{S}}$ of all major monoterpenes is significantly higher when $R$. officinalis grows in calcareous soils $(p<0.05$; Fig. 3). N, $\mathrm{P}_{\mathrm{A}}$ and $\mathrm{Ca}^{2+}$ in soil are positively correlated with $E_{\mathrm{SM}}$ of this species $(p<0.05$; Table 2). By contrast, $E_{\mathrm{SS}}$ is similar when plants grow on calcareous and siliceous sites $(p>0.05$; Fig. 2). However, when the results are expressed in percentage, $E_{\mathrm{SS}}$ is significantly higher when R. officinalis grows in siliceous sites $(15 \%)$ than when it grows in calcareous soils $(5 \%)$ (Student test,

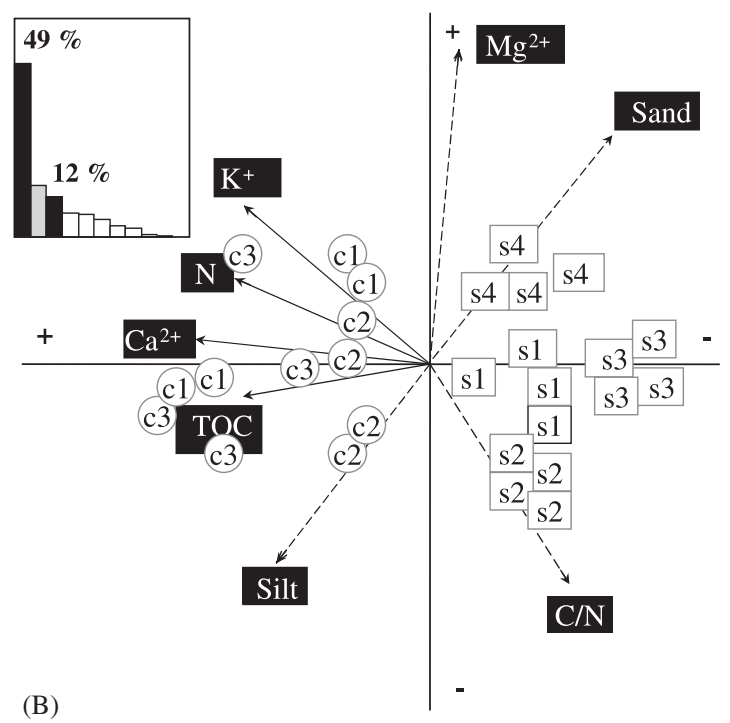

Fig. 1. Principal components analyses of the physical and chemical properties of calcareous and siliceous soils. Graphics A and B show calcareous and siliceous dichotomy according to variables explained in components 1 and 2 or components 1 and 3 , respectively. Continuous arrows explain the weight of each variable on component 1 ( $x$-axis). Discontinuous arrows explain the weight of component 2 or 3 ( $y$-axis). Circles represent calcareous sites. Squares represent siliceous sites. 


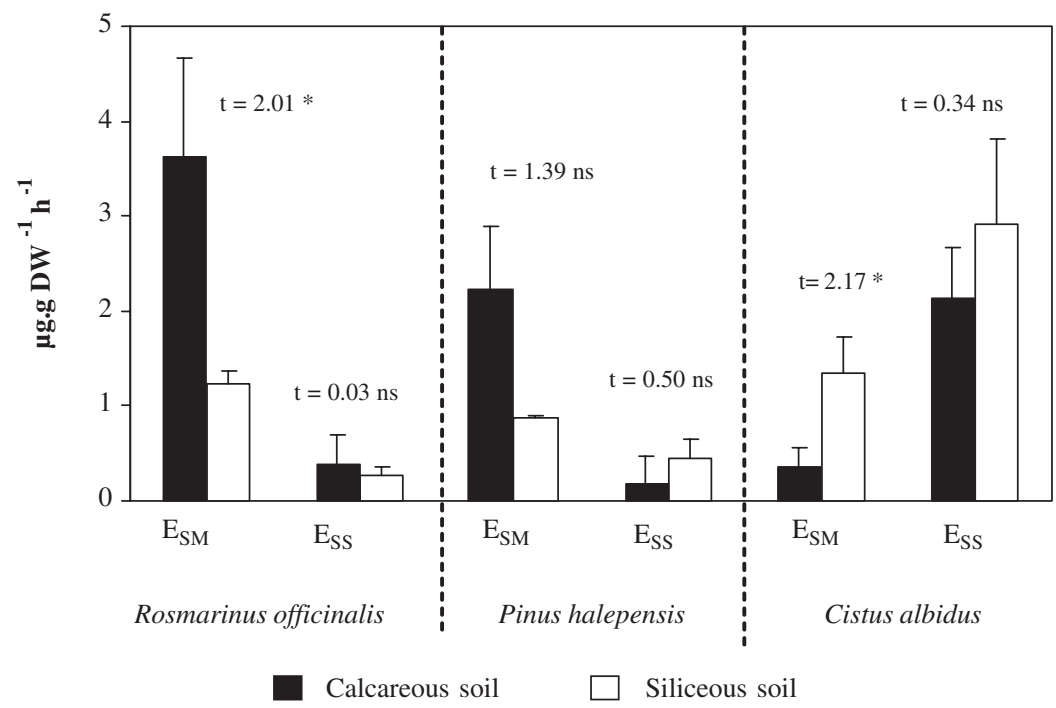

Fig. 2. Mean monoterpene and sesquiterpene standard emissions ( $E_{\mathrm{SM}}$ and $E_{\mathrm{SS}}$, respectively) of $R$. officinalis, P. halepensis and $C$. albidus in calcareous and siliceous soils. Bars indicate the SE, $n=12$. Results on different emission rates between calcareous and siliceous soils through Student test $(t)$ are also shown. $p$ : test significance, $* 0.01<p<0.05$. ns: not significant.

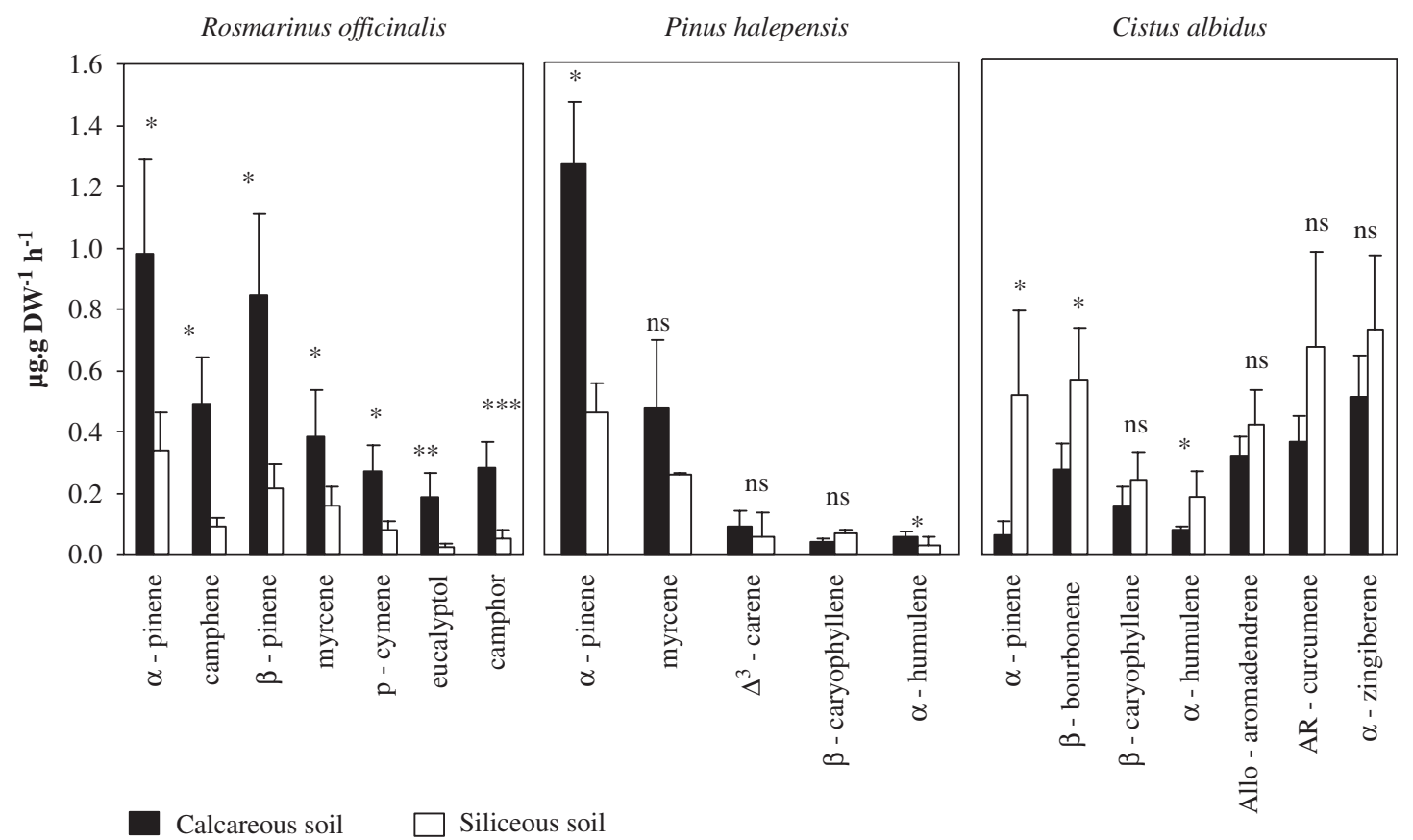

Fig. 3. Mean standard emission rates of each major compound emitted by $R$. officinalis, $P$. halepensis and $C$. albidus, in calcareous and siliceous soils. Bars indicate the SE, $n=12$. Different emission rates are tested with Student test. p: test significance, $* 0.01<p<0.05$, $* * 0.001<p<0.01, * * *<0.001$. ns: not significant $(p>0.05)$.

$p<0.05)$. No significant relationships were found between $E_{\mathrm{SS}}$ and soil nutrients $(p>0.05)$. Main sesquiterpenes detected for $R$. officinalis are $\alpha$-humulene, $\alpha$-muurolene and two unknown sesquiterpenes (Table 3 ).
P. halepensis mainly emits monoterpenes (Fig. 2, Table 3). They represent $82 \%$ of total emissions on average. Major monoterpenes are $\alpha$-pinene and myrcene (Fig. 3). $E_{\mathrm{SM}}$ does not significantly vary according to soil nature ( $p>0.05$; Fig. 2$)$. However, 
Table 2

Relationship between mean standard monoterpene emissions $\left(E_{\mathrm{SM}}\right)\left(\mu \mathrm{gg}_{\mathrm{DW}}^{-1} \mathrm{~h}^{-1}\right)$ of $R$. officinalis, P. halepensis and C. albidus and total nitrogen $(\mathrm{N})\left(\mathrm{g} \mathrm{kg}^{-1}\right)$, available phosphorous $\left(\mathrm{P}_{\mathrm{A}}\right), \mathrm{K}^{+}$and $\mathrm{Ca}^{2+}\left(\mathrm{mg} \mathrm{kg}^{-1}\right)$ in soil $(n=6)$

\begin{tabular}{|c|c|c|c|c|c|c|}
\hline \multirow[t]{2}{*}{ Species } & \multicolumn{3}{|l|}{$\mathrm{N}$} & \multicolumn{3}{|l|}{$\mathrm{P}_{\mathrm{A}}$} \\
\hline & $r$ & $P$ & Eq. $\left(y: E_{\mathrm{SM}}\right)$ & $r$ & $p$ & Eq. $\left(y: E_{\mathrm{SM}}\right)$ \\
\hline R. officinalis & 0.94 & 0.005 & $y=\exp (-0.26+0.18 \mathrm{~N})$ & 0.89 & 0.024 & $y=\exp \left(-1.63+0.057 \mathrm{P}_{\mathrm{A}}\right)$ \\
\hline P. halepensis & 0.97 & 0.001 & $y=0.55+0.21 \mathrm{~N}$ & 0.93 & 0.008 & $\left.y=-1.15+0.073 \mathrm{P}_{\mathrm{A}}\right)$ \\
\hline C. albidus ${ }^{(\mathrm{a})}$ & -0.89 & 0.016 & $y=\exp (0.47-0.32 \mathrm{~N})$ & -0.85 & 0.034 & $y=\exp \left(3.00-0.11 \mathrm{P}_{\mathrm{A}}\right)$ \\
\hline \multirow[t]{2}{*}{ C. albidus $^{(\mathrm{b})}$} & -0.90 & 0.035 & $y=\exp (-0.05-0.26 \mathrm{~N})$ & -0.87 & 0.048 & $y=\exp \left(1.87-0.08 \mathrm{P}_{\mathrm{A}}\right)$ \\
\hline & \multicolumn{3}{|l|}{$\mathrm{K}^{+}$} & \multicolumn{3}{|l|}{$\mathrm{Ca}^{2+}$} \\
\hline R. officinalis & & ns & & 0.86 & 0.025 & $y=\exp \left(-0.07+1 \cdot 3 \cdot 10^{-4} \mathrm{Ca}^{2+}\right)$ \\
\hline P. halepensis & 0.90 & 0.013 & $y=\exp \left(-0.72+2 \cdot 5 \cdot 10^{-3} \mathrm{~K}^{+}\right)$ & 0.97 & 0.000 & $y=\exp \left(-0.32+1.3 \cdot 10^{-4} \mathrm{Ca}^{2+}\right)$ \\
\hline C. albidus $^{(\mathrm{a}, \mathrm{b})}$ & & ns & & & ns & \\
\hline
\end{tabular}

$r$ : relationship coefficient, $p$ : relationship significance. ns: not significant $(p>0.05)$. Best fitting relationship is shown. (a) Superscript indicates that correlations have been calculated with all siliceous sites. (b) Superscript indicates that correlations have been calculated without data from S3.

Table 3

Terpene emission composition of R. officinalis (R.O), P. halepensis $(P . H)$ and C. albidus $(C . A)$ in calcareous and siliceous soils considered together

\begin{tabular}{|c|c|c|c|c|c|c|c|c|c|}
\hline RI & Monoterpenes & R. $O$ & P. $H$ & C. $A$ & RI & Sesquiterpenes & R. $O$ & P. $H$ & C.A \\
\hline 931 & $\alpha$-pinene & $X X X$ & $X X X$ & $X X$ & 1382 & Copaene & - & $X(\mathrm{~s})$ & $X$ \\
\hline 948 & Camphene & $X X$ & tc & $X$ & 1406 & $\beta$-bourbonene & - & $X$ & $X X$ \\
\hline 965 & Sabinene & tc & $X$ & $X$ & 1447 & $\beta$-caryophyllene & $\overline{\mathrm{tc}}$ & $X$ & $X X$ \\
\hline 970 & $\beta$-pinene & $X X X$ & $X$ & $X$ & 1476 & Unknown $1(m / z=204)$ & $X$ & - & $X X$ \\
\hline 974 & Myrcene & $X X$ & $X X$ & $X$ & 1481 & $\alpha$-humulene & $X$ & $\bar{X}$ & $X X$ \\
\hline 1014 & $\Delta^{3}$-carene & tc & $X$ & $X(\mathrm{~s})$ & 1487 & Unknown $2(m / z=204)$ & $X$ & $X$ & - \\
\hline 1036 & $p$-cymene & $X X$ & $X$ & tc & 1488 & Allo-aromadendrene & - & - & $\bar{X} X$ \\
\hline 1039 & Limonene & $X$ & tc & - & 1493 & AR-curcumene & - & $\overline{\mathrm{tc}}$ & $X X X$ \\
\hline 1042 & 1,8-cineole & $X X$ & $\operatorname{tc}(\mathrm{c})$ & - & 1502 & $\alpha$-zingiberene & - & tc & $X X X$ \\
\hline 1044 & $\beta$-trans-ocimene & - & $X$ & $\overline{\operatorname{tc}}(\mathrm{s})$ & 1519 & $\alpha$-muurolene & $\bar{X}$ & $X$ & $X$ \\
\hline 1064 & $\gamma$-terpinene & $\overline{\mathrm{tc}}$ & $X$ & $\mathrm{tc}(\mathrm{s})$ & 1522 & $\begin{array}{l}\text { Unknown } 3 \text { ( } \gamma \text {-cadinene?) } \\
(m / z=204)\end{array}$ & - & $X(\mathrm{~s})$ & $X$ \\
\hline 1094 & $\Delta$-terpinene & tc & $\operatorname{tc}(\mathrm{s})$ & tc & & & & & \\
\hline 1104 & Linalool & tc & $X$ & $\operatorname{tc}(\mathrm{s})$ & & & & & \\
\hline 1163 & Camphor & $X$ & $X$ & - & & & & & \\
\hline 1183 & Borneol & $X$ & $X$ & - & & & & & \\
\hline 1207 & $\alpha$-terpineol & $X$ & $X$ & - & & & & & \\
\hline
\end{tabular}

RI: retention index.

: if the compound was not detected in samples. $X$ : mean standard emission $\left(\mu \mathrm{g} \mathrm{g}_{\mathrm{DW}}^{-1} \mathrm{~h}^{-1}\right)$ both soils considered $(n=24) .0<X<0.1$, $\overline{0.1}<X X<0.5,0.5<X X X<2.0$. (c) and (s) denote that the compound was only detected in plants growing in calcareous and siliceous sites, respectively. tc: trace concentrations.

the main released compound, $\alpha$-pinene $(50 \%$ of total emissions), is significantly higher when plants grow in calcareous sites $(p<0.05$; Fig. 3$)$. Whereas $E_{\mathrm{SM}}$ does not significantly vary with soil nature, it is positively correlated with all main soil nutrients examined ( $\mathrm{N}, \mathrm{P}_{\mathrm{A}}, \mathrm{Ca}^{2+}$ and $\mathrm{K}^{+}, p<0.05$; Table 2$)$. $P$. halepensis also emits sesquiterpenes, which show similar emission rates in both soils ( $p>0.05$, Fig. 2$)$.
However, the percentage of all major sesquiterpenes is significantly higher in siliceous soils (Student test, $p<0.05$ ), as observed for $R$. officinalis. While these compounds represent $23 \%$ of total emissions in siliceous sites they reach $6 \%$ in calcareous sites. Moreover, $E_{\mathrm{SS}}$ is not significantly correlated with any soil nutrients examined here $(p>0.05$; Table 2$)$. Main detected sesquiterpenes are $\alpha$-humulene, 
$\beta$-caryophyllene, $\alpha$-muurolene and two unknown compounds (Table 3). $\alpha$-humulene and $\beta$-caryophyllene can be considered as major compounds. Only $E_{\mathrm{S}}$ of $\alpha$-humulene is significantly higher in plants occurring in calcareous soils $(p<0.05$; Fig. 3$)$.

$C$. albidus shows the lowest monoterpene emission rate of the three species reported in this study (Fig. 2). $E_{\mathrm{SM}}$ of this species is significantly higher in siliceous soils $(p<0.05$; Fig. 2$)$. $\alpha$-pinene explains these differences ( $p<0.05$; Fig. 3$)$, since it appears as a major compound in siliceous soils alone. $E_{\mathrm{SM}}$ of this species is negatively correlated to $\mathrm{N}$ and $\mathrm{P}_{\mathrm{A}}$ $\left(p<0.05\right.$; Table 2) and neither $\mathrm{Ca}^{2+}$ nor $\mathrm{K}^{+}$, are significantly correlated to $E_{\mathrm{SM}}(p>0.05$; Table 2$)$. When monoterpenes from S3 are excluded, results do not change and the significant negative correlation with $\mathrm{N}$ and $\mathrm{P}_{\mathrm{A}}$ is maintained ( $p<0.05$; Table 2). $E_{\mathrm{SS}}$ does not significantly vary according to the soil nature $(p<0.05$; Fig. 2$)$ and is not significantly correlated with any of the soil nutrients selected $(p>0.05)$. Numerous sesquiterpenes, such as, ARcurcumene or $\alpha$-zingiberene, constitute major compounds in emissions from $C$. albidus (Table 3 ). In contrast to $R$. officinalis and $P$. halepensis, a similar contribution to total emissions $(76 \%)$ by the main sesquiterpenes is shown in calcareous and siliceous soils (Student test, $p>0.05$ ). However, plants growing on siliceous sites show higher $E_{\mathrm{S}}$ of $\beta$-bourbonene and $\alpha$-humulene (major compounds), than those on calcareous sites ( $p<0.05$; Fig. 3 ).

\section{Discussion}

\subsection{Comparison of terpene emissions of study species with bibliographical data}

$E_{\mathrm{SM}}$ obtained in this study for $R$. officinalis was $2.38 \mu \mathrm{g} \mathrm{g}_{\mathrm{DW}}^{-1} \mathrm{~h}^{-1}$, which is within the range of results reported by Hansen et al. (1997) in spring $\left(\sim 2.2 \mu \mathrm{gg}_{\mathrm{DW}}^{-1} \mathrm{~h}^{-1}\right)$. These authors found similar major compounds to those reported here but in different relative amounts.

$E_{\mathrm{SM}}$ shown in this study for $P$. halepensis was $1.54 \mu \mathrm{gg}_{\mathrm{DW}}^{-1} \mathrm{~h}^{-1}$. This is within the order of rates reported in September and June by Owen et al. (2001), but 5-fold lower than those found in April by Peñuelas and Llusia, (1999), and almost 10-fold lower than those shown by Simon et al. (2005). Major compounds reported here for this species are $\alpha$-pinene and myrcene, as the two first works cited above reported. However, Simon et al. (2005) showed linalool and $\beta$-trans-ocimene as the main emitted compounds of this species, while these compounds are not the major compounds in this study (Fig. 3).

For both, $R$. officinalis and $P$. halepensis novel data are shown here with regard to their sesquiterpene emissions. This emission type had never been reported in previous studies, probably because of differences in analysis protocols and sampling techniques.

This study corroborates that $C$. albidus is mainly a sesquiterpene emitter, as reported by Llusià and Peñuelas, (1998). However, few and confusing data are available to date for this species in the Mediterranean region. Thus, Owen et al. (2001), did not find any detectable terpene emission in late spring for $C$. albidus. Moreover, Llusià and Peñuelas (2000) showed that this species had the highest emission rate in spring, with $30 \mu \mathrm{g} \mathrm{g}_{\mathrm{DW}}^{-1} \mathrm{~h}^{-1}$, that is 3 -fold higher than rates reported here. These authors also found that its monoterpene emissions outstripped sesquiterpene emissions all over the seasonal cycle and among sesquiterpenes, only $\beta$-caryophyllene was detected in their study. These differences may be attributable to experimental conditions, sampling techniques, sun and shade exposed leaves as well as primary and secondary leaves. Furthermore, these authors carried out their experiment at the end of April (after budbreak) while this study was carried out in the middle to end of March (during leaf growth), suggesting that the phenological state of $C$. albidus could explain differences between both studies.

The possibility of finding a wide range of emission rates for a single species underlines the complexity of (i) integrating their standard emissions in biogenic emission inventories and (ii) comparing results from estimated emissions and experimental data.

\section{2. $E_{S M}$ and $E_{S S}$ of study species in calcareous and siliceous soils}

R. officinalis and P. halepensis responded similarly to soil nature. For $R$. officinalis, $E_{\mathrm{SM}}$ (expressed in a dry mass basis and in percentage) (Fig. 2) and $E_{\mathrm{S}}$ of major monoterpenes (e.g. $\alpha$-pinene) (Fig. 3) were higher on calcareous soils. For $P$. halepensis, $E_{\mathrm{SM}}$ (expressed in percentage), $E_{\mathrm{S}}$ of $\alpha$-pinene $(50 \%$ of its total emissions) and $\alpha$-humulene were shown to be higher in plants growing in calcareous soils. Because these species are mainly calcicole species, which implies that they 
are mainly widespread on calcareous soils, the results found here could have important implications for the local photochemical pollution, since for instance, $\alpha$-pinene has been demonstrated to be highly and rapidly reactive in the atmosphere (Yu et al., 1999). The results obtained here for $P$. halepensis could be particularly relevant since this species occupies important surfaces in the Mediterranean region, in France (241 000 ha, IFN, national forest inventory data) and in the PACA Region, where the experiment took place. In this region, $P$. halepensis is considered as the main resinous species and represents $12 \%$ of the land surface.

As shown in Table 2, while soil nutrients were never correlated to $E_{\mathrm{SS}}$ of these two species, they affected similarly their $E_{\mathrm{SM}}$. Thus, $E_{\mathrm{SM}}$ of $R$. officinalis and $P$. halepensis was favored by $\mathrm{N}$, $\mathrm{P}_{\mathrm{A}}, \mathrm{Ca}^{2+}$ or $\mathrm{N}, \mathrm{P}_{\mathrm{A}}, \mathrm{K}^{+}$, and $\mathrm{Ca}^{2+}$, respectively. $\mathrm{N}$ and $P$ are considered to be the most important nutrients limiting plant growth (Schukze and Chapin, 1987), they are involved in carbon assimilation (Lambers et al., 1998) and carbon allocation to defence compounds (such as terpenes) (Mihaliak and Lincoln, 1985). However, there is evidence that these two nutrients control plant growth in different ways (Portsmuth et al., 2005) and that $P$ requirements for growth can even be higher than those of $\mathrm{N} . \mathrm{K}^{+}$is considered as the most important solute in plants, which influences complex processes such as photosynthesis (Läuchili and Bieleski, 1983). $\mathrm{Ca}^{2+}$ plays a variety of significant roles in the biological processes of plants, such as growth (Bush, 1995) or photosynthetic system protection, under high levels of irradiance and heat (Zhao and Tan, 2005). While all these nutrients could affect terpene synthesis potentially, only soil $\mathrm{N}$ has been directly put into relation with leaf terpene emissions. Thus, Gouinguene and Turlings (2002) demonstrated, by supplying different doses of $N$ fertilizers, that monoterpene and sesquiterpene emissions of corn plants, induced by the attack of an herbivore species, were at a minimum under lower nutrient contents. Moreover, Turtola et al. (2002) studied emission of Scots pine xylem after long-term fertilization (N, $\mathrm{P}$ and $\mathrm{Ca}^{2+}$ ). They found no significant terpene variations. Therefore, no study has considered constituent (in opposition to induced) terpene emissions from leaves, under either artificial or natural $\mathrm{N}, \mathrm{P}, \mathrm{K}^{+}$ and $\mathrm{Ca}^{2+}$ gradients.

Contrary to $P$. halepensis and $R$. officinalis, $E_{\mathrm{SM}}$ of C. albidus was higher in siliceous sites (Fig. 2) and was negatively correlated to $\mathrm{N}$ and $\mathrm{P}_{\mathrm{A}}$ (Table 2).
Despite the fact that $E_{\mathrm{SM}}$ of $C$. albidus was up to one order of magnitude higher in S3 than in S1 and $\mathrm{S} 2$, when data from $\mathrm{S} 3$ were discarded, the negative correlations with soil nutrients $\left(\mathrm{N}\right.$ and $\left.\mathrm{P}_{\mathrm{A}}\right)$ were maintained. Moreover, it is unlikely that other environmental factor own to S3 is implicated on the greater emissions of $C$. albidus in this site, since terpene emissions of $P$. halepensis were similar in all siliceous sites. Furthermore, S4 showed similar sand content than S3 (Fig. 1), while this particularity did not result in different emission rates of $R$. officinalis in siliceous sites. Thus, it can be affirmed that C. albidus released higher $E_{\mathrm{SM}}$ on siliceous soils for the study period.

As shown for $P$. halepensis and $R$. officinalis, $E_{\mathrm{SS}}$ of $C$. albidus was never correlated to soil nutrients (Table 2). The fact that $E_{\mathrm{SM}}$ of all study species varies according to soil nutrient availability, while their $E_{\mathrm{SS}}$ is independent on soil nutrient content could be due to the fact that these terpenes are synthesized through different pathways. This suggests that sesquiterpene synthesis pathway maybe requires different nutrient supply.

Different monoterpene dependency on the soil nature of $C$. albidus cannot be explained by its different soil preferences, because all species were mainly installed on calcareous soils. It was hypothesized that the different phenological state exhibited by $C$. albidus (leaf growth state), in comparison to that of $R$. officinalis and P. halepensis (pre-budbreak state) could explain the negative monoterpene emission dependency of $C$. albidus on soil nutrient content. Two studies seem to corroborate this hypothesis. Firstly, Lerdau et al. (1995) found that leaf terpene emissions of Pseudotsuga menziesii Mirb., were correlated negatively to plant $\mathrm{N}$ content during leaf expansion exclusively, while the opposite response was observed at the pre-budbreak in spring, as this study shows for $R$. officinalis and $P$. halepensis. Secondly, Robles (1998) suggested that $\mathrm{N}$ uptake of $C$. albidus during leaf growth in Provence was mostly allocated to budbreak and that this allocation pattern occurred particularly in calcareous soils. Consequently, exceptionally during this phenological state, C. albidus leaves showed lesser nitrogen content at calcareous sites than at siliceous sites. Moreover, the fact that $C$. albidus releases monoterpenes which are not previously stored in leaf pools (Llusià and Peñuelas, 2000), as occurs in the other two species, could be linked to its different response to soil nutrient availability. Thus, while $R$. officinalis (Moretti et al., 1998), and 
P. halepensis (Llusià and Peñuelas, 2000) store both monoterpenes and sesquiterpenes, only sesquiterpenes have been detected in leaves of $C$. albidus (Robles and Garzino, 1998). This implies that monoterpene emissions of $P$. halepensis and $R$. officinalis are potentially more dependent on monoterpene pools, whose size and number have been found to increase under higher nitrogen concentrations (Bjorkman et al., 1998).

Results obtained here support the idea that different emission rates of study species growing in calcareous and siliceous soils is a consequence of the different nutrient availability owing the specific nature of each kind of soil. However, the possibility that these results were linked to the occurrence of different ecotypes on calcareous and siliceous soils was examined. An ecotype consists of a population adapted genetically to particular ecological conditions (Ramade, 2002). These genetical differences explain why stands which belong to a different ecotype show often different morphological traits or different emission composition, as occurs for ecotypes of Quercus suber L. in different European localities (Loreto, 2002). In this study, the occurrence of different ecotypes for the same species is ruled out, since $\alpha$-pinene and $\beta$-pinene from $R$. officinalis, $\alpha$-pinene and myrcene from $P$. halepensis, and AR-curcumene and $\alpha$-zingiberene from $C$. albidus were the most widely released compounds in both soils.

\section{Conclusion}

This study shows that the differentiation between calcareous and siliceous soils may be helpful for explaining the overall monoterpene emission variability between individuals of the same species, while for sesquiterpenes this differentiation is restricted to individual compounds. Moreover, $\mathrm{N}$ and $\mathrm{P}_{\mathrm{A}}$ concentrations in soil seem to be more efficient soil properties than $\mathrm{Ca}^{2+}$ and $\mathrm{K}^{+}$for estimating $E_{\mathrm{SM}}$ of study species. None of these soil nutrients is efficient for assessing $E_{\mathrm{SS}}$, suggesting that nutrient requirements for sesquiterpene synthesis are different and that sesquiterpenes must be rather modified by other environmental factors. It should be also borne in mind that the same species studied here could show different responses at other seasonal cycles, since the pattern of nutrient allocation to terpene synthesis has been demonstrated to vary according to the phenological state (Lerdau et al., 1995). Finally, this study highlights that further work on sesquiterpene dependency on other abiotic factors is necessary since they can constitute the most important emissions in some species.

\section{Acknowledgments}

This research was primarily funded by the French Agriculture Minister (DERF), the Environmental agency (ADEME) and the PACA region. We would like to thank Sylvie Dupouyet and Dr. Christiane Rolando for her collaboration in measurement campaigns, Christine Ballini for her advice on soil analyses and Jean-Philippe Mévy for his help on chromatographic analyses. We thank Mr. Michael Paul for improvements to the English.

\section{References}

Barnola, L.F., Cedeño, A., 2000. Inter-population differences in the essential oils of Pinus caribaea needles. Biochemical Systematics and Ecology 28, 923-931.

Bertin, N., Staudt, M., Hansen, U., Seufert, G., Ciccioli, P., Foster, P., Fugit, J.L., Torres, L., 1997. Diurnal and seasonal course of monoterpene emissions from Quercus ilex (L.) under natural conditions - applications of light and temperature algorithms. Atmospheric Environment 31, 135-144.

Bjorkman, C., Kyto, M., Larsson, S., Niemela, P., 1998. Different responses of two carbon-based defences in Scots pine needles to nitrogen fertilization. Ecoscience 5, 502-507.

Bush, D.S., 1995. Calcium regulation in plant-cells and its role in signaling. Annual Review of Plant Physiology and Plant Molecular Biology 46, 95-122.

Flamini, G., Cioni, P.L., Morelli, I., Maccioni, S., Baldini, R., 2004. Phytochemical typologies in some populations of Myrtus communis L. on caprione promontory (East Liguria, Italy). Food Chemistry 85, 599-604.

Gouinguene, S.P., Turlings, T.C.J., 2002. The effects of abiotic factors on induced volatile emissions in corn plants. Plant Physiology 129, 1296-1307.

Guenther, A., 2002. The contribution of reactive carbon emissions from vegetation to the carbon balance of terrestrial ecosystems. Chemosphere 49, 837-844.

Guenther, A., Hewitt, C.N., Erickson, D., Fall, R., Geron, C., Graedel, T., Harley, P., Klinger, L., Lerdau, M., Mckay, W.A., Pierce, T., Scholes, B., Steinbrecher, R., Tallamraju, R., Taylor, J., Zimmerman, P., 1995. A global-model of natural volatile organic-compound emissions. Journal of Geophysical Research-Atmospheres 100, 8873-8892.

Hampel, D., Mosandl, A., Wust, M., 2005. Biosynthesis of mono- and sesquiterpenes in carrot roots and leaves (Daucus carota L.): metabolic cross talk of cytosolic mevalonate and plastidial methylerythritol phosphate pathways. Phytochemistry $66,305-311$.

Hansen, U., Seufert, G., 1999. Terpenoid emission from Citrus sinensis (L.) OSBECK under drought stress. Physics and Chemistry of the Earth Part B-Hydrology Oceans and Atmosphere 24, 681-687. 
Hansen, U., Van Eijk, J., Bertin, N., Staudt, M., Kotzias, D., Seufert, G., Fugit, J.L., Torres, L., Cecinato, A., Brancaleoni, E., Ciccioli, P., Bomboi, T., 1997. Biogenic emissions and $\mathrm{CO}_{2}$ gas exchange investigated on four Mediterranean shrubs. Atmospheric Environment 31, 157-166.

Lambers, H., Chapin, F.S., Pons, T.L., 1998. Plant Physiological Ecology. Springer, New York.

Läuchili, A., Bieleski, R.L., 1983. Encyclopedia of plant physiology. In: Pirson, A., Zimmerman, M.H. (Eds.), Inorganic Nutrition. Springer, Berlin, Heidelberg, New York, Tokyo, p. 449.

Lerdau, M., Matson, P., Fall, R., Monson, R., 1995. Ecological controls over monoterpene emissions from Douglas-Fir (Pseudotsuga-Menziesii). Ecology 76, 2640-2647.

Llusià, J., Peñuelas, J., 1998. Changes in terpene content and emission in potted Mediterranean woody plants under severe drought. Canadian Journal of Botany-Revue Canadienne De Botanique 76, 1366-1373.

Llusià, J., Peñuelas, J., 2000. Seasonal patterns of terpene content and emission from seven Mediterranean woody species in field conditions. American Journal of Botany 87, 133-140.

Loreto, F., 2002. Distribution of isoprenoid emitters in the Quercus genus around the world: chemo-taxonomical implications and evolutionary considerations based on the ecological function of the trait. Perspectives in Plant Ecology Evolution and Systematics 5, 185-192.

Mihaliak, C.A., Lincoln, D.E., 1985. Growth-pattern and carbon allocation to volatile leaf terpenes under nitrogen-limiting conditions in Heterotheca subaxillaris (Asteraceae). Oecologia 66, 423-426.

Moretti, M., Peana, A., Passino, G., Solinas, V., 1998. Effects of soil properties on yield and composition of Rosmarinus officinalis essential oil. Essential Oil Research 10, 261-267.

Owen, S.M., Boissard, C., Hewitt, N., 2001. Volatile organic compounds (VOCs) emitted from 40 Mediterranean plant species: VOC speciation and extrapolation to habitat scale. Atmospheric Environment 35, 5393-5409.

Peñuelas, J., Llusia, J., 1999. Short-term responses of terpene emission rates to experimental changes of PFD in Pinus halepensis and Quercus ilex in summer field conditions. Environmental and Experimental Botany 42, 61-68.

Portsmuth, A., Niinemets, U., Truus, L., Pensa, M., 2005. Biomass allocation and growth rates in Pinus sylvestris are interactively modified by nitrogen and phosphorus availabilities and by tree size and age. Canadian Journal of Forest Research-Revue Canadienne De Recherche Forestiere 35, 2346-2359.

Ramade, F., 2002. Dictionnaire encyclopédique de l'écologie et des sciences de l'environnement. Dunod, Paris.

Robles, C. 1998. Fonctionnement des cistaies à Cistus albidus L. et Cistus monspeliensis L. en Provence calcaire et siliceuse à travers la mesure des réactions écophysiologiques. Thèse de Doctorat en Sciences, biologie de populations et Ecologie, Faculté de Biologie, Université de Provence, Marseille.

Robles, C., Garzino, S., 1998. Essential oil composition of Cistus albidus leaves. Phytochemistry 48, 1341-1345.

Robles, C., Garzino, S., 2000. Infraspecific variability in the essential oil composition of Cistus monspeliensis leaves. Phytochemistry 53, 71-75.

Sabillon, D., Cremades, L.V., 2001. Diurnal and seasonal variation of monoterpene emission rates for two typical Mediterranean species (Pinus pinea and Quercus ilex) from field measurements-relationship with temperature and PAR. Atmospheric Environment 35, 4419-4431.

Schukze, E.D., Chapin III, F.S., 1987. Plant specialization to environments of different resources availability. In: Schukze, E.D., Zwolfer, H. (Eds.), Potentials and Limitations of Ecosystem Analysis. Springer, Berlin, pp. 120-148.

Schweingruber, F.H., 1988. Tree Rings. Basics and Applications of Dendrochronology, Dordrecht.

Simon, V., Dumergues, L., Solignac, G., Torres, L., 2005. Biogenic emissions from Pinus halepensis: a typical species of the Mediterranean area. Atmospheric Environment 74, $37-48$.

Staudt, M., Bertin, N., 1998. Light and temperature dependence of the emission of cyclic and acyclic monoterpenes from holm oak (Quercus ilex L.) leaves. Plant Cell and Environment 21, 385-395.

Street, R.A., Owen, S., Duckham, S.C., Boissard, C., Hewitt, C.N., 1997. Effect of habitat and age on variations in volatile organic compound (VOC) emissions from Quercus ilex and Pinus pinea. Atmospheric Environment 31, 89-100.

Tingey, D.T., Manning, M., Grothaus, L.C., Burns, W.F., 1980. Influence of light and temperature on monoterpene emission rates from slash pine. Plant Physiology 65, 797-807.

Tsigaridis, K., Kanakidou, M., 2002. Importance of volatile organic compounds photochemistry over a forested area in central Greece. Atmospheric Environment 36, 3137-3146.

Turtola, S., Manninen, A.M., Holopainen, J.K., Levula, T., Raitio, H., Kainulainen, P., 2002. Secondary metabolite concentrations and terpene emissions of Scots pine xylem after long-term forest fertilization. Journal of Environmental Quality 31, 1694-1701.

Yu, J.Z., Cocker, D.R., Griffin, R.J., Flagan, R.C., Seinfeld, J.H., 1999. Gas-phase ozone oxidation of monoterpenes: gaseous and particulate products. Journal of Atmospheric Chemistry 34, 207-258.

Zhao, H.J., Tan, J.F., 2005. Role of calcium ion in protection against heat and high irradiance stress-induced oxidative damage to photosynthesis of wheat leaves. Photosynthetica 43, 473-476. 